\title{
Contamination Assessment of Potentially Toxic Metals in Road-Side Surface Soils Along Iwo-Ibadan Expressway, Nigeria
}

\author{
Emmanuel Adewuni Akintunde ${ }^{1}$, Odunayo Timothy Ore, *, Solomon Sunday Durodola ${ }^{2}$, \\ Jolaade Eunice Sharaibi ${ }^{2}$, Oluwaseun Blessing Adegbite ${ }^{2}$ \\ ${ }^{1}$ Department of Chemistry and Industrial Chemistry, Bowen University, Iwo, Nigeria \\ ${ }^{2}$ Department of Chemistry, Obafemi Awolowo University, Ile-Ife, Nigeria
}

Email address:

oreodunayo@yahoo.com (O. T. Ore)

*Corresponding author

\section{To cite this article:}

Emmanuel Adewuni Akintunde, Odunayo Timothy Ore, Solomon Sunday Durodola, Jolaade Eunice Sharaibi, Oluwaseun Blessing Adegbite. Contamination Assessment of Potentially Toxic Metals in Road-Side Surface Soils Along Iwo-Ibadan Expressway, Nigeria. Colloid and Surface Science. Vol. 5, No. 1, 2020, pp. 1-5. doi: 10.11648/j.css.20200501.11

Received: December 3, 2019; Accepted: December 25, 2019; Published: January 6, 2020

\begin{abstract}
This study was carried out to assess the contamination levels of road-side surface soils by potentially toxic metals due to their persistence and bioaccumulative nature in the ecosystem. Surface soils were sampled at various equidistance points along Iwo-Ibadan expressway, Nigeria and were then digested and analyzed for elemental concentrations using Atomic Absorption Spectrophotometer. $\mathrm{Zn}(72.91 \mathrm{mg} / \mathrm{kg})$ had the highest mean concentration followed by $\mathrm{Pb}(54.66 \mathrm{mg} / \mathrm{kg}), \mathrm{Mn}$ $(31.32 \mathrm{mg} / \mathrm{kg}), \mathrm{Fe}(12.16 \mathrm{mg} / \mathrm{kg}), \mathrm{Cd}(11.92 \mathrm{mg} / \mathrm{kg})$ and $\mathrm{Cu}(4.06 \mathrm{mg} / \mathrm{kg})$. Variation in the elemental levels across the sampling points was a reflection of the variation in traffic density. The results of the contamination factor and geoaccumulation index indicated varying degrees of contamination. The modified degree of contamination and the pollution load index suggested that the road-side surface soils are contaminated with the metals. Cluster analysis indicated that the metals are associated with car components and vehicular emissions. It is therefore recommended that strict regulations be put in place against the use of leaded gasoline as vehicular fuels. Adequate and frequent monitoring of highway contamination by metals as a result of their bioaccumulative tendencies is also suggested.
\end{abstract}

Keywords: Contamination; Road-side, Soil, Toxic Metal, Vehicular Emission

\section{Introduction}

Heavy metals enlist a relatively large series of elements with specific density over $5 \mathrm{~g} / \mathrm{cm}^{3}$ and relative atomic mass above 40. Environmental pollution by metals became extensive with the fillip in mining and industrial activities during the last two centuries. The current worldwide mine production of $\mathrm{Cu}, \mathrm{Cd}, \mathrm{Pb}$ and $\mathrm{Hg}$ is considerably huge [1]. These pollutants, ultimately derived from a growing number of diverse anthropogenic sources, have had enormous impact on different ecosystem [2-3]. Fifty-three of the ninety naturally occurring elements are heavy metals [4]. Of these, $\mathrm{Fe}$, Mo and $\mathrm{Mn}$ are important as micronutrients, while $\mathrm{Zn}$, $\mathrm{Ni}, \mathrm{Cu}, \mathrm{Co}$ and $\mathrm{Cr}$ are toxic elements, but have importance as trace elements. $\mathrm{Ag}, \mathrm{As}, \mathrm{Hg}, \mathrm{Cd}$, and $\mathrm{Pb}$ have no known function as nutrients, and seem to be toxic to plants and microorganism [5]. The majority of the heavy metals are toxic to the living organism and even those considered as essential can be toxic if present in excess. The heavy metals can impair important biochemical process posing a threat to human health, plant growth and animal life [1, 6-8]. Heavy metals are an important toxicity source for soils. Heavy metal contamination of soil is based on three main sources: road traffic (automobiles), industrial activities, and weathered materials [9-10]. In terms of roadside soil, the most effective contaminant source is vehicle traffic. Ward et al. [11] reported that heavy metal pollution from automotive emissions affects roadside surface soils. Roadside soils often show a high degree of contamination that can be attributed to motor vehicles. Various researchers have found that the 
concentrations of the metals $\mathrm{Pb}, \mathrm{Cu}, \mathrm{Zn}, \mathrm{Cd}$ and Ni decrease rapidly within 10 to $50 \mathrm{~m}$ from the roadsides [12-13]. According to Panek and Zawodny [14], pollution of roadside soils and plants by combustion of leaded petrol products is localized and usually limited to a belt of several metres wide on either side of the road, and that for similar topography and vegetation, the level of pollution decreases with the distance from the road. Due to their cation exchange capacity, complexing organic substances, oxides and carbonates have high retention capacity for heavy metals. Hence contamination levels increase continuously as long as the nearby sources remain active. Nevertheless, some heavy metals attached to the soil particles can be removed from the soil surfaces and get translocated elsewhere by the action of water and wind [15-17]. Heavy metals found in roadside dust are significant environmental pollutants of growing concern in recent years, that public and scientific attention has increasingly focused on its contamination and effects on human and other living creatures [18]. The release of heavy metals is one of the most significant environmental problems caused by anthropogenic activities such as urban road construction, quarrying, agriculture, waste incinerations, sewage disposal, bush burning, vehicle exhausts, industrial discharges, oil lubricants, automobile parts [19], corrosion of building materials, atmospheric deposition [20] and particulate emission [21]. The presence of heavy metals has been considered as useful indicators for contamination in surface soil, sediment and dust environments [22]. These metals are bio-accumulative and there are possibilities that these metals can reach a critical value where human health is threatened [23]. Several contributions to road-side soil pollution by heavy metals arise from various anthropogenic inputs including vehicular emissions. Due to the potential toxicity and bioaccumulative ability of these metals, the need therefore arises to assess the possible contamination of these metals in road-side surface soils.

\section{Materials and Methods}

\subsection{Study Area, Sampling, Sample Storage and Preparation}

The study area is between Iwo in Osun State and Ibadan in Oyo State. Iwo is a host of a private tertiary institution while Ibadan is the largest city in Nigeria and host of several tertiary institutions. Ibadan is situated on latitude $7^{\circ} 24^{\prime} 39^{\prime}$ 'N and longitude $3^{\circ} 54^{\prime} 21^{\prime \prime} \mathrm{E}$. It has a population of $5,580,894$ million according to the National Population Census in 2006. It is situated within the tropical forest zone but close to the boundary between the forest and the derived savanna. Surface soil samples were collected from ten (10) different sampling points along Iwo-Ibadan expressway. The samples were collected by scooping the soil samples into air tight containers and labeled accordingly. The surface soil samples were air-dried; rocks and pebbles were removed before pulverization using a mortar and pestle. The pulverized soil samples were then passed through a $500 \mu \mathrm{m}$ filter sieve to achieve uniform particle size.

\subsection{Metal Analysis}

Pulverized soil samples $(1.0 \mathrm{~g})$ each was pretreated using $10 \mathrm{~mL}$ Aqua regia (mixture of concentrated $\mathrm{HCl}$ and $\mathrm{HNO}_{3}$ acids in the ratio 3:1, British Drug House, BDH Analar grade). This was then heated on a hot plate at $70^{\circ} \mathrm{C}$ to near dryness and then cooled, and $5 \mathrm{~mL}$ of $2 \mathrm{M} \mathrm{HCl}$ was added. This was filtered into $50 \mathrm{~mL}$ volumetric flask and made up with double distilled water [24]. The filtrates were analyzed for the metals ( $\mathrm{Zn}, \mathrm{Mn}, \mathrm{Cu}, \mathrm{Cd}, \mathrm{Pb}$ and $\mathrm{Fe}$ ) using Atomic Absorption Spectrophotometer, Model PG 990 at Bowen University, Iwo, Osun State, Nigeria. Blank determination was also carried out.

\subsection{Quality Assurance and Quality Control}

All the glassware and sample bottles were cleaned using the procedure of Laxen and Harrison (1981). The containers were thoroughly washed with detergent rinsed with water, soaked in $10 \% \mathrm{HNO}_{3}$ for 48 hours. Thereafter, they were thoroughly rinsed with distilled water and by doubly distilled water and then kept dried at $105^{\circ} \mathrm{C}$ in the oven. All analyses were performed in triplicates.

Recovery analysis was done to ascertain the accuracy of the method/analytical procedure used by spiking $1 \mathrm{~g}$ each of two different soil samples with $5.0 \mu \mathrm{g} / \mathrm{g}$ standard mixture of the heavy metal solutions ( $\mathrm{Pb}, \mathrm{Cu}, \mathrm{Cd}, \mathrm{Fe}$ and $\mathrm{Zn})$. Standard metal solutions were used to fortify the sample with the specified metal, digested and taken for AAS analysis. The percentage recovery $(\% \mathrm{R})$ for the potentially toxic metals was determined as given below:

$$
\% \mathrm{R}=\left[\left(\mathrm{C}-\mathrm{C}^{\prime}\right) / \mathrm{A}\right] \times 100
$$

Where $\mathrm{C}=$ heavy metal concentration in the spiked soil sample, $\mathrm{C}^{\prime}=$ heavy metal concentration in the unspiked sample and $\mathrm{A}=$ the amount of heavy metal used for spiking [24].

\subsection{Data Treatment}

For the interpretation of the geochemical data the following statistical methods were used: Descriptive statistics (mean, range, standard deviation and coefficient of variation) were performed in addition to contamination factor, geoaccumulation index, pollution load index and modified degree of contamination to interpret the obtained data. Cluster analysis was used to identify the possible sources as well as the correlation among the analyzed potentially toxic metals [25-29].

\section{Results and Discussion}

\subsection{Result of Recovery Analysis}

The reliability of the analytical procedures adopted in this study was tested in terms of sensitivity, recovery, precision and accuracy. Table 1 shows the values for $\%$ recovery for the analyzed metals under experimental conditions used. The recoveries of metals in spiked sample were between 84.5 - 
$95 \%$. Since the mean percentage recoveries for all analyte were within an acceptable range (70-110\%); this gives credence to the reliability of the results of this study.

Table 1. Analytical Results for Calibration Curve and Percentage Recovery $(\% R)$.

\begin{tabular}{llll}
\hline Metals & $\begin{array}{l}\text { Amount spiked } \\
\text { (mg/kg) }\end{array}$ & $\begin{array}{l}\text { Amount recovered } \\
\text { (mg/kg) }\end{array}$ & \% Recovery \\
\hline $\mathrm{Pb}$ & 5.0 & 4.25 & 85 \\
$\mathrm{Cu}$ & 5.0 & 4.75 & 95 \\
$\mathrm{Cd}$ & 5.0 & 4.35 & 87 \\
$\mathrm{Zn}$ & 5.0 & 4.225 & 84.5 \\
$\mathrm{Fe}$ & 5.0 & 4.45 & 89 \\
\hline
\end{tabular}

The levels of the elemental composition of the road-side surface soils of the study area are presented in Table 2. Variations existed in the levels of the potentially toxic metals in the road-side surface soils. Zinc had the highest mean concentration while Copper had the least mean concentration. Sampling point A had relatively high levels of Zinc and Lead. This indicated a direct contribution of traffic pollution to the road-side soils as a result of the closeness of sampling point A to the edge of the road. According to previous studies, the levels of metals in road-side surface soils is dependent on the distance from the road and is considered an indicator of traffic-related pollution [30-32].

\subsection{Elemental Analysis}

Table 2. Levels of Toxic Metals in Road-Side Surface Soils (mg/kg).

\begin{tabular}{|c|c|c|c|c|c|c|}
\hline Samples & $\mathbf{Z n}$ & Mn & $\mathbf{C u}$ & Cd & $\mathbf{P b}$ & $\mathrm{Fe}$ \\
\hline $\mathrm{A}$ & 298.05 & 2.45 & 2.05 & 0.85 & 152.05 & ND \\
\hline B & 46.35 & 14.45 & 0.95 & 0.15 & 65.95 & ND \\
\hline $\mathrm{C}$ & 3.9 & 14.5 & 3.95 & 20.85 & 8.95 & 5 \\
\hline $\mathrm{D}$ & 34.85 & 96.1 & 10.05 & ND & 4.55 & 1.55 \\
\hline E & 162.5 & 50 & 1.2 & 0.45 & 52.25 & ND \\
\hline $\mathrm{F}$ & 3.9 & 2.35 & 3.7 & ND & 3.7 & 2.7 \\
\hline G & 32.5 & 5.65 & 1.65 & 5 & 103.65 & ND \\
\hline I & 69.95 & 33.05 & 10.05 & ND & 61.05 & ND \\
\hline $\mathrm{J}$ & 72.95 & 77.75 & 1.45 & 50 & 72.95 & 50 \\
\hline Range & $3.90-298.05$ & $2.35-96.10$ & $0.95-10.05$ & $\mathrm{ND}-50$ & $3.70-152.05$ & ND - 50 \\
\hline Mean \pm SD & $72.91 \pm 29.20$ & $31.32 \pm 10.44$ & $4.06 \pm 1.09$ & $11.92 \pm 5.05$ & $54.66 \pm 15.16$ & $12.16 \pm 4.90$ \\
\hline CV (\%) & 40.05 & 33.33 & 26.84 & 42.36 & 27.73 & 40.29 \\
\hline
\end{tabular}

$\mathrm{ND}=$ Not detected

The variation that existed in the different sampling points could be due to the action of wind across the sampling points. Most particulates carrying traffic-related elements like $\mathrm{Zn}, \mathrm{Pb}$, $\mathrm{Cu}, \mathrm{Cd}$, emitted from vehicles are usually deposited on road-side surface soils not more than $0-5 \mathrm{~m}$, however, some can be carried a longer distance by wind. The variation could also be a reflection of traffic density at some points than the others. The relatively high concentration of Lead is a cause for concern because leaded gasoline has been verboten in Nigeria since 2005 . Nevertheless, it is perceived that some marketers are still in the business of selling blends of the leaded gasoline with unleaded gasoline, which might be a reason for the high levels of $\mathrm{Pb}$. However, crude oil contains $\mathrm{Pb}$, alongside the other metals as geogenic impurities [33]. In contrast, the sources of $\mathrm{Cu}, \mathrm{Zn}$ and $\mathrm{Cd}$ are car components, tyre abrasion, lubricants, industrial and incinerator emissions [34-35]. The soil contents of Fe were found to be almost independent on the distance from the road. This could be an indication that they were not directly related to traffic pollution, they could be a reflection of their natural sources or the background concentration of the study area. Generally, the levels of the metals in the road-side surface soils follow the order: $\mathrm{Zn}>\mathrm{Pb}>\mathrm{Mn}>\mathrm{Fe}>\mathrm{Cd}>\mathrm{Cu}$.

Figure 1 is a figure showing the hierarchical cluster analysis of the investigated metals in the road-side surface soils. Three major clustering groups are shown in the dendrogram. Group A showed a clustering relationship between $\mathrm{Pb}$ and $\mathrm{Zn}$. Group $\mathrm{B}$ showed a clustering relationship between $\mathrm{Fe}$ and $\mathrm{Mn}$. Group $\mathrm{C}$ showed the closest inter-element clustering between $\mathrm{Cd}, \mathrm{Fe}$ and $\mathrm{Cu}$. Interelement clustering relationships are known to indicate common sources and/or similar background levels. $\mathrm{Cd}$ and $\mathrm{Cu}$, for instance, are elements known to be associated with engine parts and motor oil. The clustering relationship between $\mathrm{Fe}$ and $\mathrm{Mn}$ could be attributed to natural sources or similar background levels in the study area.

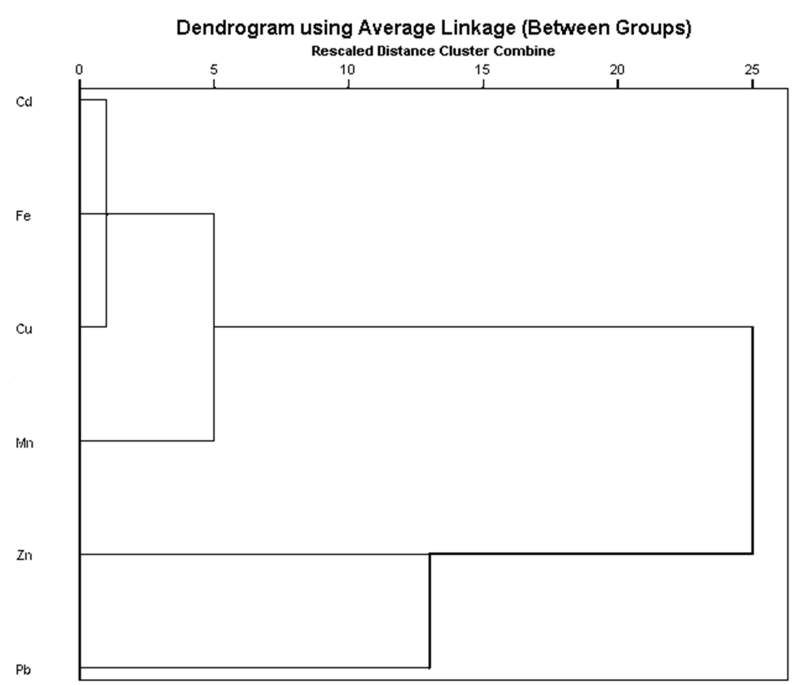

Figure 1. Cluster Analysis of the Potentially Toxic Metals in the Road-Side Surface Soils. 


\subsection{Contamination Indices of the Potentially Toxic Metals in the Road-Side Surface Soils}

The indices of contamination of the investigated metals in the road-side surface soils are presented in Table 3 . The roadside soils showed low contamination by Mn and Fe. Mn and Fe levels in the soils might be due to natural sources or other unknown sources rather than contamination arising from vehicular emissions. The road-side soils showed considerable contamination by $\mathrm{Cu}$ and very high contamination by $\mathrm{Zn}$ and $\mathrm{Pb}$.

Table 3. Indices of Contamination of the Potentially Toxic Metals in the Road-Side Surface Soils.

\begin{tabular}{lllll}
\hline Metal & Mean & Geochemical baseline & CF & I geo \\
\hline $\mathrm{Zn}$ & 72.91 & 3 & 24.30 & 4.01 \\
$\mathrm{Mn}$ & 31.32 & 40 & 0.78 & -0.93 \\
$\mathrm{Cu}$ & 4.06 & 0.8 & 5.07 & 1.75 \\
$\mathrm{Cd}$ & 11.92 & $\mathrm{~N} . \mathrm{A}$ & $\mathrm{N} . \mathrm{A}$ & $\mathrm{N} . \mathrm{A}$ \\
$\mathrm{Pb}$ & 54.66 & 5.3 & 10.31 & 2.78 \\
$\mathrm{Fe}$ & 12.16 & 1600 & 0.007 & -7.62 \\
$\mathrm{mCd}$ & & & 8.09 & \\
$\mathrm{PLI}$ & & & 1.49 & \\
\hline
\end{tabular}

$\mathrm{CF}=$ contamination factor, $\mathrm{I}_{\mathrm{geo}}=$ Geo-accumulation index, $\mathrm{mCd}=$ Modified degree of contamination, PLI $=$ Pollution load index.

The results of the geo-accumulation index indicated that the road-side surface soils were unpolluted with $\mathrm{Mn}$ and Fe, moderately polluted with $\mathrm{Cu}$, moderately to strongly polluted with $\mathrm{Pb}$ and strongly to extremely polluted with $\mathrm{Zn}$. The result of the modified degree of contamination showed that the soils exhibited very high degree of contamination, while the pollution load index indicated a deterioration of site quality by the investigated metals.

\subsection{Comparison of Elemental Profiles of Road-Side Surface Soils with Other Studies}

The elemental levels of the road-side surface soils were compared with other studies, and their results are presented in Table 4. Variations existed in the metal levels of this study and that of the other studies reported in Bosnia and Herzegovina [36] and Turkey [37]. The toxic metals (Zn, Mn, $\mathrm{Cu}, \mathrm{Pb}$ and $\mathrm{Fe}$ ) were all higher in the other studies. Cd level reported in this study was relatively higher. It has been reported that load on heavy metal contents in surface soils and their variability depend upon the traffic density and the distance [38-40].

Table 4. Comparison of Elemental Profiles of Road-Side Surface Soils with Other Studies.

\begin{tabular}{llll}
\hline Metal & This Study & Skrbic [36] & Isen et al. [37] \\
\hline $\mathrm{Zn}$ & 72.91 & 139 & 229.07 \\
$\mathrm{Mn}$ & 31.32 & 860 & 129.2 \\
$\mathrm{Cu}$ & 4.06 & 32.2 & 69.42 \\
$\mathrm{Cd}$ & 11.92 & 2.78 & 6.65 \\
$\mathrm{~Pb}$ & 54.66 & 74.7 & 227.6 \\
$\mathrm{Fe}$ & 12.16 & 11801 & 113.8 \\
\hline
\end{tabular}

\section{Conclusion and Recommendation}

Concentrations of potentially toxic metals were analyzed in road-side surface soils along Iwo-Ibadan expressway, Nigeria. Vehicular emissions as a function of traffic density was found to be a major source of the contamination by the metals. The relatively high $\mathrm{Pb}$ levels indicated that leaded gasoline is still in use in Nigeria despite its proscription since 2005. Cluster analysis grouped the metals according to their natural sources and anthropogenic inputs respectively. The indices of contamination indicated a deterioration of the road-side soils by the metals. Increased urbanization and the use of second-hand vehicles in the country necessitates a further monitoring of the elemental levels of the road-side. It is also recommended that strict regulations be enforced on the use of leaded gasoline in the country.

\section{References}

[1] Jarup, L., 2003. Hazards of heavy metal contamination. Brit. Med. Bull. 68, 167-182.

[2] Macfarlane, G. R., Burchett, M. D., 2001. Mar. Poll. Bull. 42, 233-240.

[3] Macfarlane, G. R., Burchett, M. D., 2002. Mar. Env. Res. 54, 65-84.

[4] Weast, R. C., 1984. CRC Handbook of Chemistry and Physics, 64th ed.. CRC Press, Boca Raton.

[5] Nies, D. H., 1999. Appl. Microb. Biotech. 51, 730-750.

[6] Silva, A. L. O., Barrocas, P. R. G., Jacob, S. C., Moreira, J. C., 2005. Brazil. J. Plant Physiol. 17, 79-93.

[7] Ali, S. T., Mahmooduzzafar, Abdin, M. Z., Iqbal, M., 2008. J. Env. Biol. 29, 661-668.

[8] Yoshinori, I., Shouta, M. M. N., Kaampwe, M., Kennedy, C., Hiroki, T., Naoharu, M., Mayumi, I., 2010. Afr. J. Env. Sci. Tech. 4 (11), 729-739.

[9] Akhter M. S., Madany I. M. Heavy metals in street and house dust in Bahrain. Water Air Soil Poll. 66, 111, 1993.

[10] Abu-Allaban M., Gillies J. A., Alan W., Gertler A. W., Clayton R., Proffitt D. Tailpipe, resuspended road dust and break wear emission factors from on-road vehicles. Atmos. Environ. 37, 52, 2003.

[11] Ward L. N., Brooks R. R., Roberts E. Heavy-metal pollution from automotive emissions and its effect on roadside soils and pasture species in New Zealand. Environ. Sci. Technol. 11, (9), 917, 1977.

[12] Joshi SR, Kumar R, Bhagobaty RK, Thokchom S (2010). Impact of pollution on microbial activities in sub-tropical forest soil of north east India. Research Journal of Environmental Sciences 4 (3): 280-287.

[13] Pagotto C, Rèmy N, Legret M, Le Cloirec P (2001). Heavy metal pollution on road dust and roadside soil near a major rural highway. Environ. Technol. 22: 307-319.

[14] Panek E, Zawodny Z (1993). Trace metals in the roadside mountain soils of Sierra Nevada, Spain. Environ. Geochem. Health. 15 (4): 229-235. 
[15] Harrison RM, Laxen DPH, Wilson SJ (1981). Chemical association of lead, cadmium, copper and zinc in street dust and roadside soils. Environ. Sci. Tech. 15: 1378-1383.

[16] Ndiokwere CL (1984). A study of heavy metal pollution from motor vehicle emission and its effect on roadside soil, vegetation and crops of Nigeria. Environ. Pollut. Ser. B 7: 3542 .

[17] Ghrefat H, Yusuf N (2006). Assessing Mn, Fe, Cu, Zn and Cd pollution in bottom sediments of Wadi Al-Arab Dam, Jordan. Chemosphere 65: 2114-2121.

[18] Wang, X. S, Qin, Y and Sun, S. X (2005): Accumulation and sources of heavy metals in urban topsoil: A case study from the city of Xuzhou, China, Environ. Geology, 48, 101-107.

[19] Ho, I. B. and Tai, K. M. (1988). Elevated levels of lead and other. Metals in roadside soil and grass and their use to monitor aerial metal depositions in Hong Kong. Environ. Pollut., 49: 37-51.

[20] Adriano, D. C (2001). Trace elements in terrestrial environments: biogeochemistry, bioavailability and risks of metals, $\left(2^{\text {nd }}\right.$ ed $)$. Springer, New York, p. 867.

[21] Sutherland R. A, Tolosa C. A, Tack F. M. G, Verloo M. G (2000): Characterization of selected element concentration and enrichment ratios in background and anthropogenically impacted roadside areas Arch. Environ. Contam. Toxicol. 38: 428-438.

[22] Ubwa, S. T, Abah, J, Ada, C. A and Alechenu, E. "Levels of some heavy metals contamination of street dust in the industrial and high traffic density areas of Jos Metropolis", Journal of Biodiversity and Environmental Sciences, Vol. 3: Issue 7; 2013, pp 13-21.

[23] Censi, P, S. E. Spoto, F. Saiano, M. Sprovieri and S. Mazzola et al., 2006. Heavy metals in coastal water system. A case study from the North Western Gulf of Thailand. Chemosphere, 64: 1167-1176.

[24] O. T. Ore, F. M. Adebiyi (2019). Determination and Speciation Analyses of Potentially Toxic Metals in OilImpacted Soils Around Mechanic Workshops for Human and Ecological Risks Assessment. Research \& Reviews: Journal of Green Chemistry. 1 (3): 1-16.

[25] Salbu, B., Krekling, T. and Oughton, D. H. 1998. Characterization of radioactive particles in the environment. Analyst, 123: 843-849.

[26] Buccolieri, A., Buccolieri, G. and Cardellicchio, N. 2006. Potential toxic Metals in Marine Sediments of Taranto Gulf (Ionian Sea, Southern Italy). Marine chemistry. 99: 227-235.

[27] Abrahim, G. M. S. and Parker, P. J.. Assessment of heavy metal enrichment factors and the degree of contamination in marine sediments from Tamaki Estuary, Auckland, New
Zealand, Environmental Monitoring and Assessment. 2008. 136 (1-3): 227-238 p.

[28] Duodu, G. O., Goonetilleke, A., Ayoko, G. A., 2016. Comparison of pollution indices for the assessment of heavy metal in Brisbane River sediment. Environmental Pollution. 219, 1077-1091 p.

[29] O. T. Ore, G. E. Akhigbe, A. O. Adegunwa, E. O. Olalekan, D. A. Ayeni, O. M. Omirin, P. E. Adebiyi. Total and Chemical Speciation Analyses of Potential Toxic Metals in Refuse Dumpsite Soils. World Journal of Applied Chemistry. Vol. 4, No. 2, 2019, pp. 25-35. doi: 10.11648/j.wjac.20190402.12.

[30] Sutherland, R. A., Tolosa, C. A., 2001. Variation in total and extractable elements with distance from roads in an urban watershed, Honolulu, Hawaii. Water Air Soil Pollut. 127, 315 338 .

[31] Swaileh, K. M., Hussein, R. M., Abu-Elhaj, S., 2004. Assessment of heavy metal contamination in roadside surface soil and vegetation from the West Bank. Arch. Environ. Contam. Toxicol. 47, 23-30.

[32] Crnkovi' c, D., Risti ' c, M., Antonovi' c, D., 2006. Distribution of heavy metals and arsenic in soils of Belgrade (Serbia and Montenegro). Soil Sediment Contam. 15, 581589.

[33] Kummer, U., Pacyna, J., Pacyna, E., Friedrich, R., 2009. Assessment of heavy metal releases from the use phase of road transport in Europe. Atmos. Environ. 43, 640-647.

[34] Markus, J. A., McBratney, A. B., 1996. An urban soil study: heavy metals in Glebe, Australia. Aust. J. Soil Res. 34, 453465.

[35] Wilcke, W., Muller, S., Kanchanakool, N., Zech, W., 1998. Urban soil contamination in Bangkok: heavy metal and aluminium portioning in topsoils. Geoderma 86, 211-228.

[36] Biljana Skrbi'c, Sne`zana Milovac, Milan Matavulj. 2012. Multielement profiles of soil, road dust, tree bark and woodrotten fungi collected at various distances from highfrequency road in urban area. Ecological Indicators 13: 168177. doi: 10.1016/j.ecolind.2011.05.023.

[37] Hülya Isen, Hüseyin Altundag, Can Serkan Keskin. 2013. Determination of Heavy Metal Contamination in Roadside Surface Soil by Sequential Extraction. Pol. J. Environ. Stud. Vol. 22, No. 5, 1381-1385.

[38] Motto, H. L., Danies, R. P., Chilko, D. M., Motto, C. K., 1970. Environ. Sci. Qual. 4, 231-237.

[39] Bai, J., Cui, B., Wang, O., Gao, H., Ding, Q., 2008. Stoch Env Res Risk Ass. DIO 10.1007/S00477-008-0219-5.

[40] Nakayama, M. M. S., Ikenaka, Y., Muzandu, K., Choongo, K., Oroszlany, B., Teraoka, H., Mizuno, N., Ishizuka, M., 2010. Env. Contamin. Toxicol. 59 (2), 291-300. 